\title{
Soil Loss under Different Cropping Systems in Highlands of Uganda
}

\author{
Nabalegwa M Wambede*, Asaba Joyfred, Turyahabwe Remigio \\ Department of Geography, Faculty of Arts and Social Studies, Kyambogo University, Uganda
}

Copyright $\subset 2016$ by authors, all rights reserved. Authors agree that this article remains permanently open access under the terms of the Creative Commons Attribution License 4.0 International License

\begin{abstract}
This study assessed the influence of cropping systems on soil loss on agricultural slopes. The specific objectives were; to measure soil loss from different cropping systems and to compare the amount of soil loss from the different cropping systems. Soil loss was monitored for one growing season on experimental plots. Only dominant cropping systems were considered including; mixed cropping (maize and beans), onion on contours, and millet sole cropping system. One control treatment characterized by spear grass and short trees and other shrubs was considered. Data about cropping systems was obtained with the help of observation and questionnaires while that about soil and nutrient loss was obtained through experimentation and laboratory analysis. For experimental purposes, 3 slope sites at different slope ranges were considered as a representative sample for the whole sub county that is, lower slopes $\left(08^{0}-16^{0}\right)$, middle slope $\left(17^{0}-25^{0}\right)$ and upper slope $\left(26^{0}-31^{0}\right.$.) At each of the slope sites, the above treatments were established from which data about run off, soil loss were measured after each erosive rain storm. The data obtained included: The most erosive system at all slope sites was mixed cropping, with7.98 t/ha, $19 \mathrm{t} / \mathrm{ha}$ and $25 \mathrm{t} / \mathrm{ha}$ at the lower, middle and upper slopes respectively, this was followed by contour with $5.68 \mathrm{t} / \mathrm{ha}, 12 \mathrm{t} / \mathrm{ha}$ and $16 \mathrm{t} / \mathrm{ha}$ at the lower, middle and upper slopes respectively while the sole cropping had the lowest i.e. $2.6 \mathrm{t} / \mathrm{ha}, 10.33 \mathrm{t} / \mathrm{ha}$ and 14.52 $\mathrm{t} / \mathrm{ha}$ at the lower, middle and upper slopes respectively. The control plot had the lowest soil loss at all sites with $0.094 \mathrm{t} / \mathrm{ha}$, $0.36 \mathrm{t} / \mathrm{ha}$, and $0.54 \mathrm{t} / \mathrm{ha}$ at the lower, middle and upper slopes respectively. It was recommended that at the upper slopes, sole cropping system should be emphasized. This should be of pasture- like crops especially grain crops that grow close to the surface or/and have fibrous rooting system such as millet, sorghum and upland rice. At the middle slopes, millet (grain) sole cropping system is a better option just like at the upper slopes. However contour cropping system can also be applied, while at the lower slopes, all cropping systems can be applied including mixed, sole, inter cropping and ridging cropping systems.
\end{abstract}

Keywords Cropping Systems, Erosion, Soil Loss

\section{Background to the Study}

Throughout the world, land productivity has declined particularly due to human activity. This has resulted into environmental degradation and food shortages. Soil erosion by water plays a major role in this phenomenon. Once it occurs it is extremely difficult to reverse since it takes 500 years to form $25 \mathrm{~mm}$ depth of soil under agricultural conditions, Pimentel [1].

Soil is a thin layer of organic and inorganic materials on the earth's surface that supports plant growth. It can also be defined as a thin surface layer of the earth which is formed by the breakdown of rocks by weathering processes like, chemical, mechanical and biological weathering.

Soil is formed through various processes including Weathering, which is the starting process in soil formation that involves disintegration and decomposition of rocks into smaller particles part of which is soil. Other processes include; leaching, elluviation, illuviation, humification, mineralization, calcification and lateralization, Youndeowei [2]. Soil formation and erosion take place at the same time, where by soil erosion proceeds in processes like splash, sheet, rill, gully and stream. The erosion phenomenon has been studied by different researchers in different regions, for example, according to Wild [3], soil erosion is the removal of part of the soil or the whole soil by the action of either wind or water. There are two basic types of erosion including; geological erosion and accelerated erosion, where by geological erosion is the one that takes place under natural conditions when land surface and native vegetation have not been interfered with by human activity while the accelerated type is the one that is as a result of human activities such as cultivation and grazing [2].

There has been soil erosion as long as there have been farmers [3]. For example in northern mountains of Mesopotamia, soil erosion is associated with early and probably the first farmers, about 10,000 years ago, who felled trees and cultivated the cleared land in addition to 
overgrazing of sheep and goats.

Likewise Morgan [4] notes that rapid erosion by wind and water has been a problem since man began cultivating land. He adds that soil erosion has remained a problem in the U.SA, many tropical and temperate countries including Great Britain and Germany due to man's interference through clearing land for cultivation. The factors influencing soil loss include; rainfall, run off, wind, slope and plant cover and presence or absence of conservation methods.

In a review of soil loss under natural conditions Young [5], quotes the rates in the order of $0.0045 \mathrm{Kg} \mathrm{m}^{-2} \mathrm{y}^{-1}$ for steep relief. For comparison rates from agricultural land in the range of 4.5 to $45.0 \mathrm{Kg} \mathrm{m}^{-2} \mathrm{y}^{-1}$ are classed as accelerated erosion which is disastrous in the tropical regions. Soil erosion in Africa is considered to be greater than in other tropical regions (Sanchez, [6]. Dudal quoted by [6] has put the mean annual soil loss at 7 ton. $\mathrm{ha}^{-1} \mathrm{yr}^{-1}$ in Africa compared to $0.8 \mathrm{t} \mathrm{ha}^{-1} \mathrm{yr}^{-1}$ in Europe. These figures indicate severity of erosion in Africa.

According to Lal [7], erosion has continued to be a problem in both tropical and temperate zones. However for related soils and topography, its magnitude is greater in the tropical region. This has been attributed to more frequent and intense rains with high energy loads, unstable soils, and poor agricultural practices.

In east Africa the most complex and grave hindrance of agricultural development is soil erosion. Water erosion has increased especially in Kenya and Uganda as a consequence of intense field cultivation and overgrazing in addition to other factors Bovill [8].

Even in Kenya where some substantial research about soil loss has been carried out, still serious rates of erosion are reported in various regions of the country. For example, in Machakos region, soil losses recorded from runoff plots were 109,49 , and 6.1 ton $\mathrm{ha}^{-1} \mathrm{yr}^{-1}$ in overgrazed, maize and ploughed fields respectively. While the cultivated fields of upper Sagana, Maragua, Thika and Chania produced soil loss of 12.29, 26.1, 7.86 and $11.14 \mathrm{t} \mathrm{ha}^{-1} \mathrm{yr}^{-1}$ respectively Moore [9], in the upper Masinga dam catchment high erosion rates of $23.3 \mathrm{t} \mathrm{ha}^{-1} \mathrm{yr}^{-1}$ were also reported from farms with the highest erosion hazard, lowest soil resistance and lowest vegetation regeneration. On the other hand farms with opposite characteristics yielded approximately $11.1 \mathrm{t}$ ha $^{-1} \mathrm{yr}^{-1}$ Mutisya et al, [10].

In Uganda soil deterioration by erosion even on fertile soils undermines the agricultural sector which greatly upholds the country's economy. Erosion is widely spread in all the highlands and other areas of the country Tumuhairwe, [11]. Signs of adverse soil erosion such as exposed sub soils, reduced crop yields are becoming more apparent in the south and central Uganda due to the pressure of intensive agriculture and rolling topography [11].

According to Wayland [12], soil erosion is a historical problem that Uganda has continued to suffer up to today. NEMA [13] reveals that, $46.5 \%$ of the land area in 19 districts is suffering from soil erosion particularly those that are densely populated especially Kabale, Kisoro, and Mbale where continuous cultivation on steep slopes has increased rill and sheet erosion.

Mutisya et al., [10] observed that, the changing land use in an area with greater emphasis on annual maize cropping on open fields without any conservation practice puts the soils on slopping lands at great risk of erosion. Erosion under perennial crops like banana and coffee systems is expected to be reduced due to the presence of more protective cover and mulch, however it should be noted that in this research, slope angle and cropping systems were not specified yet differences in these accelerate erosion at different rates.

Morgan [4], in explaining the functionality of USLE (universal soil loss equation) noted that all predictive soil loss equations currently in use so far refers to drainage basins and do not provide suitable techniques for assessing soil loss from smaller areas such as hill slopes and fields. However according to Arnold [14], in Uganda, today there is a growing concern and interest in soil issues at various institutions. For example, erosion plot studies have been set up in Kabanyoro research station, Kawanda agricultural research station and in Kabale to assess soil loss in the areas.

According to Dorsey et al, [15 \& 7], the first step in combating soil erosion is to ascertain where and how much soil is being lost under several land uses. Morgan [4] notes that cultivation has been noted to increase the erodibilty of some soil types such as sandy and loamy soils. He adds that different plant covers afford different degrees of protection such that even relative changes in plant covers can result into considerable increase in erosion. The researcher therefore wished to establish the influence of cropping systems as land covers on soil loss. This is because patterns portrayed by different cropping systems determine the spacing and therefore the percentage ground cover. This therefore necessitates a close look at the cropping systems because cropping systems provide ground cover, hence erosion.

Wild [3], define a cropping system as the spatial organization or arrangement of crops in a given garden or piece of land. Cropping systems refers to a system of growing crops including a rotation of different crops on the same area and growing the same crop on the same field year-in, year-out. It should be noted that cropping systems are different from farming systems in that cropping systems are a 'sub set' of farming systems. Whereas farming systems are somehow permanent, cropping systems change from season to season and from garden to garden [1]. Morgan and Wild [ 4 \& 3 $]$ outlined a number of options of cropping systems including mono cropping, mixed, intercropping, strip, contour cropping among others.

Morgan [4] noted that care must be taken when choosing a cropping system to use. He warns that crops grown in rows like maize in a sole cropping system are the least effective and gives rise to more serious erosion problem. This is because of high percentage of bare ground particularly in the early stages of growth. He goes ahead to advises farmers that in this case, there is need to mix such crops with protection effective crops in a logical cropping system. For contour cropping, the suitable contour bunds should be as wide as 


\section{5- 2 meters on steeper slopes.}

It should be noted that the choice of the cropping system by the farmers is dependent upon the socio-economic status of the farmers. For example; FAO [16], notes that, throughout the world, bush fallowing which was used to increase soil fertility in the past cannot be practiced any more due to increase in population pressure on land. In Africa, customary land tenure system has led to fragmentation of land and permits free choice of land use.

NEMA [13] observes that land fragmentation in Kabale and intense cropping are partly responsible for increased soil erosion. This is due to high demand for land for settlement and cultivation to produce enough food. Man has encroached on the fragile steep slopes of hills using different cropping systems and technologies that have accelerated soil erosion. To satisfy the increasing food demand, the Bakiga have opted for fast yielding crops such as Irish potatoes which are grown in ridges hence ridging cropping system. In Rubirizi district and Kirugu sub-county in particular, the fertile volcanic soils have attracted farmers from different parts of the former greater Bushenyi District to settle there and in so doing this increased the population and pushed some farmers to the steep hill slopes where they have cultivated crops from foot hills to hill tops on most hills using various cropping systems most of which are inappropriate at slope angles they are located. For example, maize mono cropping at upper slopes more over in lines which has accelerated soil erosion, therefore, a need to establish suitable and sustainable pattern of cropping systems in the hills of Kirugu sub-county by first assessing the influence of the existing cropping systems on soil loss, hence a need for this research study.

\subsection{Objectives}

The general objective of this study was to assess the influence of cropping systems on soil loss on the agricultural slopes in the study area, with a view of proposing appropriate and sustainable cropping systems that limit soil loss.

The specific objectives were; to establish the cropping systems in the study area, to measure and establish the soil loss from different cropping systems and to compare the amount of soil loss from different cropping systems.

\section{Methodology}

\subsection{Research Design}

The study adopted an experimental design which involved setting up experiments to collect data on soil loss and runoff under existing cropping systems. The experiments were set up on peasant farm plots located on different slope sites/ facets. The slope sites were selected in such a way to represent a range of cropping systems and slope angles commonly found on upslope peasant farms in Kirugu sub-county. Three slope facet ranges were established comprising of most arable portions of the hill slopes on which experiments were established, that is lower slope $\left(08-16^{0}\right)$, middle slope $\left(17-25^{\circ}\right)$ and upper slope $\left(26-31^{0}\right)$. In this study segmentation of the slope was at points of significant break in slope angle as described by Speight [17] to enable systematic recording of field observations.

Hill slope unit divisions are essential because they are mostly the result of specific slope processes response in local environment [4] and this indeed means different soil erosion process mechanism unique to those particular units. On the hill slopes the three facets were identified and erosion plots established on each of the three facets. The experiments were carried out for one annual crop growing season of march-July as it is the first growing season of the calendar year which is even wet. A replica of erosion plots were established on each of the three slope facets of the hill site which were monitored throughout the growing season. On each slope facet at least three major existing cropping systems and one control plot under natural pasture was taken. Data on soil loss and runoff from each plot was collected from a week after planting up to harvesting and after each erosive rain storm.

\subsubsection{Sample Size}

Out of the six hills, one hill (Kyengoma hill in Kirugu parish) of 1090 meters above sea level was selected as a representative sample. Beyond $1090 \mathrm{~m}$, hills were rocky with very thin soils and there was no cultivation. The reasons for this choice included; comparing low lands in the northern region of the sub county with raised relief in the southern region, the researcher found that erosion studies are more relevant in erosion prone areas. More so this hill had all the cropping systems found on all other hills in the sub county, this hill was the highest and therefore had all the heights and slope angles found on other hills in the sub county. Also given the fact that the soil type on all the hills is the same due to the same mode of formation (volcanicity), as hill therefore summarized characteristics of the rest of the hills in the sub county, that is to say, the rest of the hills were represented here and therefore recommendations for this site applies to all other hills depending on their respective heights and angles hence the best choice of the location of study sites.

\subsubsection{Methods Used}

The methods used for data collection included observation, interview and questionnaire to get information about cropping systems. The interview and questionnaires were responded to by the farmers, land lords and tenants. Field experiments were also carried out to determine the amount of soil loss and laboratory analysis of the soil nutrients in the eroded soil. Secondary data was obtained by use of documentary review.

\subsubsection{Tools Used}

The tools used included plastic tanks, tape measure, questionnaires, rain gauge, Abney level, weighing scale, what man's filter papers, tipping bucket, metallic sheets, Gelarch troughs, and PVC plastic pipes among others to 
measure rain fall, run off, soil loss, slope angle, plot length and width of contour guide were made using the tools listed above.

\section{Results}

\subsection{Cropping Systems in the Study Area}

A cropping system is the spatial organization or arrangement of crops in a given garden or piece of land. Information gathered through interviews, questionnaires and field observations indicated that crops grown in the research area included; beans, millet, onions, maize, bananas and cassava among others and are grown in varying cropping systems such as mixed, intercropping, Mono/sole, contour, and strip cropping systems. The choice of these cropping systems had been influenced by several factors including mainly land tenure system, culture, market for the products and the levels of education of the farmers. Analysis of the information about the farming systems on the six hills found in the study in area is presented in table1.

From table 1, it can be observed that the most dominant cropping system were mixed and sole cropping systems with 73 and 55 gardens respectively were observed from the field. They were followed by contour with 40 gardens, rotation 26 gardens, strip 16 gardens and ridging 9 gardens. Intercropping of Millet and maize was observed. This was practiced in such a way that the maize rows were planted across the hill and the space between the rows was $3-3 \mathrm{~m}$ and the space between the maize plants in each row was $30-40$ $\mathrm{cm}$ apart. In between the rows, millet seeds were casted. Other alley intercrops were maize and beans in a more or less similar arrangement as millet and maize. Irish/sweet potatoes were also intercropped with some maize plants where long ridges were planted with potatoes while between the ridges some maize was grown. Farmers carry out this to ensure food security and as a control measure to the run off because each ridge is as high as $60 \mathrm{~cm}$. An interview with the farmers revealed that the previous season was for cotton which was intercropped with beans that were planted between the rows of cotton. The space between cotton rows is approximately $60 \mathrm{~cm}$ while the space between beans plants is $20-25 \mathrm{~cm}$. on the whole this system consisted of twelve gardens accounting for $5.2 \%$ of the total gardens in the study area. The system is practiced not only because it produces varied crop harvests in one growing season but also the system reduces the risk of soil loss.

Rotational cropping was identified in this study area as mentioned in the above. Information from questionnaire and interviews revealed that there are two main growing seasons that is to say, between February - July as well as August-December each year hence rotations are done on seasonal basis. In the first season, beans, potatoes, millet, maize and onions dominate, while the following season of the same year, gardens are rotated with cotton, cassava and ground nuts. It accounted for $11.3 \%$ of the cropping systems. Sole cropping was also indentifies accounting for $23.8 \%$ of the gardens observed. Crops grown under this system included onions, maize, millet, cassava, and annual crops like bananas and coffee. It was the second dominant cropping system in the study area.

Strip cropping accounted for $6.9 \%$ of the total gardens observed in the area. The crops grown under this system were dominated by millet, followed by beans downwards and finally maize. It is commonly practiced on the rented land. The lowest portions (foot hill) are not rented but are for the land lords and are therefore permanently covered by Banana plantations.

The choice of the crop on these hills is dictated by the land lord. This is in an attempt to ensure reduced run off and effective rotations of the crops to maintain fertility. However, the spacing between crops is determined by the tenants.

The most commonly grown crop on contours was onions. Wherever onions were grown on all the hill slopes, contour guides (bunds) were put in place. Most bunds were made of stones and grass as well as some crop residues and were as high as $15-20 \mathrm{~cm}$ and as wide as $0.5-0.8 \mathrm{~m}$. (see plate 3.7). The distance between a contour guide/bund and another decreased with increase in steepness ranging from $14-30 \mathrm{~m}$ in lower slopes Other crops grown on contours were millet, where the contour bunds are kept as grass bunds across the hill. Forty gardens were observed on all the six hills accounting for $17.3 \%$ of the total gardens found in the area hence the third most dominant cropping system.

Table 1. Cropping systems found in the study area

\begin{tabular}{|c|c|c|c|c|c|c|c|c|}
\hline Cropping system & \multicolumn{9}{|c|}{ Number of gardens observed on different hills } \\
\hline & $\mathrm{A}$ & $\mathrm{B}$ & $\mathrm{C}$ & $\mathrm{D}$ & $\mathrm{E}$ & $\mathrm{F}$ & Total & $\%$ \\
\hline Mixed cropping & 11 & 16 & 10 & 9 & 19 & 8 & 73 & 31.6 \\
\hline Sole cropping & 6 & 12 & 9 & 8 & 16 & 4 & 55 & 23.8 \\
\hline Contour cropping & 3 & 8 & 6 & 6 & 11 & 6 & 40 & 17.3 \\
\hline Rotation cropping & 6 & 7 & - & 6 & 7 & - & 26 & 11.3 \\
\hline Strip cropping & 3 & 6 & - & - & 2 & 5 & 16 & 6.9 \\
\hline Intercropping(Alley) & 4 & 4 & 1 & 2 & - & 1 & 12 & 5.2 \\
\hline Ridging & 2 & 1 & - & - & 6 & - & 9 & 3.9 \\
\hline
\end{tabular}

Source: Field data.

Hills: $\mathrm{A}=$ Kaberengye. $\mathrm{B}=$ Kyengoma. $\mathrm{C}=$ Kikumbo. $\mathrm{D}=$ Kafuro. $\mathrm{E}=$ Kyamwiga. $\mathrm{F}=$ Kyamukumba. 
Mixed cropping was also identified in this area. It accounted $31.6 \%$ of the gardens in this area. The commonest mixture was that of Beans and maize on all the hills. Some farmers had haphazardly mixed both crops by sowing them while others had planted maize in lines (rows or columns) and casted beans in between. The commonest are casted beans and maize. Other mixed crops included millet and maize, millet and sun flower. These are dispersed in the millet garden. It was the most dominant in the area. Ridging was the least cropping system practiced in the area. It accounted for $3.9 \%$ of the observed systems. This is involved the growing of crops on mounds constructed using.

\subsection{Soil Loss from Different Cropping Systems at Different Slope Sites}

The experiments were set to determine soil loss in each of the 3 cropping systems and one control plot on each of the 3 slope segments namely; Lower, middle and upper slopes. The results obtained are presented in table 2 below;

Table 2. Total Soil loss from different cropping systems in different slope Segments

\begin{tabular}{|c|c|c|c|}
\hline Treatment & \multicolumn{3}{|c|}{${\text { Total soil loss }\left(\mathrm{tha}^{-1}\right)}^{-1}$} \\
\hline & Lower Slope & Middle Slope & Upper slope \\
\hline $\begin{array}{c}\text { Sole/mono cropping } \\
\text { system }\end{array}$ & 2.64 & 10.33 & 14.52 \\
\hline $\begin{array}{c}\text { Mixed cropping } \\
\text { system }\end{array}$ & 7.98 & 19 & 25 \\
\hline $\begin{array}{c}\text { Contour cropping } \\
\text { system }\end{array}$ & 5.68 & 12 & 16 \\
\hline Control & 0.094 & 0.36 & 0.54 \\
\hline
\end{tabular}

3.2.1. Soil loss from different cropping systems at the lower slopes

For experimental purposes the following land unit characteristics were considered that namely; slope length and slope angle, soil depth, soil texture and cover crops. At the lower slope facet/site all the above characteristics were similar (uniform) for all experimental plots. What varied were the cropping systems. The differences in runoff and soil loss were attributed to the differences in cropping systems portrayed by differences in crops covering the ground.

At this site the uniform characteristics were slope lengths of $15 \mathrm{~m}$, slope angle of $08^{0}-16^{0}$, the soil texture was loam ( $52 \%$ sand $22 \%$ clay, $26 \%$ silt), depth of the top dark layer of the soil was $47 \mathrm{~cm}$ on average. The cropping systems considered here were millet sole, mixed cropping (Beans and maize), onions in contour cropping system and one control plot characterized by spear grass and other bushes. Other soil characteristics at this site included; OM (organic matter) $9.8 \%, \mathrm{~N}$ (Nitrogen) $1.7 \%, \mathrm{P}$ (phosphorous) $31 \mathrm{ppm}$ (parts per million), $\mathrm{K}$ (potassium) $2.1 \mathrm{me} / 100 \mathrm{~g}$ (mills equivalent per 100 grams), $\mathrm{pH} 4.5$ and a rainfall range of $26-73 \mathrm{~mm}$. Measurements of soil loss from individual cropping systems were made and the results in table 2 are for the total soil loss for the 9 weeks.

The results in table 2 show that, when land on the lower slope had not been interfered with, only a total of $0.09 \mathrm{t} / \mathrm{ha}$ of soil is lost in one growing season. Mixed cropping of maize and beans registered the highest soil loss of $7.98 \mathrm{t} / \mathrm{ha}$, followed by contour cropping system with $5.68 \mathrm{t} / \mathrm{ha}$ and millet solo cropping system with $2.64 \mathrm{t} / \mathrm{ha}$. Soil loss was highest in the mixed cropping system because maize intercropped with beans takes long to develop a dense network of roots to bind the soil particles together hence high soil loss. More loss also comes from this system towards the harvesting period when beans shed of their leaves. Millet sole cropping system registered the least loss of $2.64 \mathrm{t} / \mathrm{ha}$ but this was higher in the initial stages of crop growth compared to the later growth stages when the ground is covered by crops to more or less like the natural pasture and fibrous roots had rebuilt the soil structure. The difference between the highest and lowest soil loss treatment in this experiment was $0.87 \mathrm{t} / \mathrm{ha}$.

\subsubsection{Soil loss from different cropping systems at the middle slopes}

At the middle slope site, the uniform characteristics considered were; the slope length of $15 \mathrm{~m}$, slope angle of 17 $25^{\circ}$, texture was sandy loam ( $62 \%$ sand $19 \%$ clay, $19 \%$ silt), depth of the top dark layer of soil was $41 \mathrm{~cm}$ on average. The cropping systems were similar as on the lower slope. Other characteristics were organic matter $(\mathrm{OM}) 7.6 \%$, Nitrogen $(\mathrm{N})$ $1.3 \%$, P 26 ppm, Potassium (K) $1.21 \mathrm{me} / 100 \mathrm{~g}, \mathrm{pH} 4.5$ and rain fall range of $26-73 \mathrm{~mm}$.

From the results in table 2, it can be deduced that, when the land on the middle slope has not been interfered with, a total of only $0.36 \mathrm{t} / \mathrm{ha}$ of soil is lost within the runoff for one growing season. Mixed cropping system of maize and beans registered the highest soil loss of $19 \mathrm{t} / \mathrm{ha}$, followed by contour cropping with soil loss of $12 \mathrm{t} / \mathrm{ha}$ and the millet sole cropping system with a total soil loss of $10.33 \mathrm{t} / \mathrm{h}$. like in the lower slope, Soil loss in the middle slope was highest in the Mixed cropping of maize and beans because these crops take long to bind the soil particles together hence more soil loss. More soil was also lost from this system towards the harvesting period when beans shed of their leaves. Soil loss was lowest in the millet sole cropping system but this was however more in the initial stages of crop growth after which the ground is covered more or less like the natural pasture as fibrous roots rebuild the soil structure.

\subsubsection{Soil loss from different cropping systems at the upper slopes}

At the upper slope site the uniform characteristics considered were slope length of $15 \mathrm{~m}$, slope angle of $26-33^{\circ}$, texture was sandy loam ( $64 \%$ sand, $14 \%$ clay, $22 \%$ silt), depth of the dark layer of top soil was $26 \mathrm{~cm}$, and the cropping systems considered were the same as above. Other soil characteristics included organic matter $(\mathrm{OM})$ 6.2\%, Nitrogen $(\mathrm{N})=0.9 \%$, phosphorus $(\mathrm{P})=16 \mathrm{ppm}$, Potassium $(\mathrm{K})=1.1 \mathrm{me} / 100 \mathrm{~g}$ and the $\mathrm{pH}$ was 5.0 .and rain fall ranges of between $26-73 \mathrm{~mm}$. The results shows that, when the land on the upper slope has not been interfered with, a total of 
only $0.54 \mathrm{t} / \mathrm{ha}$ of soil was lost through the runoff for one growing season. Mixed cropping of maize and beans registered the highest soil loss with $25 \mathrm{t} / \mathrm{ha}$, followed by the contour cropping system with soil loss of $16 \mathrm{t} / \mathrm{ha}$ and millet sole cropping system with $14.52 \mathrm{t} / \mathrm{ha}$.

Generally of all the treatments in this study, mixed cropping system registered the highest soil loss in the lower, middle and upper slope segments. This is unlike in the upper Machakos region of Kenya where the highest soil loss of 49 t/ha was registered from maize sole cropping system as indicated by Mutisya et. Al., [10]. This was however higher than $25 \mathrm{t} /$ ha from mixed cropping system that was the highest on upper slopes in this study. This may be due to differences in rain fall totals and slope angles. Millet sole cropping recorded the lowest total loss in the three slope segments. The soil loss variability at different slope sites from different treatments was attributed to changes in the slope gradient whereby increase in the gradient led to increase in the runoff and soil loss. In the same way, increase in the rain fall amount led to increase in the soil loss. This does not differ from Morgan's [4] argument that erosion would normally be expected to increase with an increase in slope steepness and slope length as a result of respective increase in velocity and volume of surface run off.

\subsection{Comparison of soil loss between different cropping systems at different slopes, at different stages of growth}

A comparison of soil loss from the different cropping systems (millet sole, mixed maize and beans, onion contour and one control treatment) was made at each slope segment. This was done following the order of lower, middle, and upper slopes.

\subsubsection{A comparison of soil loss between the different cropping systems at different crop growth stages at the lower slopes.}

The data about soil loss from different cropping systems at the lower slopes was tabulated, in table 3 to show a comparison of soil loss between the different cropping systems at different crop growth stages. Table 4 portrays the pattern or trend of change in the soil loss under different cropping systems with change in crop growth stage. It shows that soil loss was higher in all treatments in week one than the rest of the weeks since the soil had just been tilled and was loose with no surface cover and so could easily be eroded. However it should be noted that soil loss was highest in the mixed cropping system with $3.2 \mathrm{t} / \mathrm{ha}$ and contour with $2.09 \mathrm{t} / \mathrm{ha}$. This was followed by millet sole cropping system with $1.86 \mathrm{t} / \mathrm{ha}$ while the control had the least soil loss of 0.08 $\mathrm{t} / \mathrm{ha}$. Soil loss from the mixed was higher than that from the control treatment by $3.12 \mathrm{t} / \mathrm{ha}$.

Table 3. A comparison of soil loss between the different cropping systems at different crop growth stages at the lower slopes.

\begin{tabular}{|c|c|c|c|c|}
\hline \multirow{2}{*}{$\begin{array}{c}\text { Crop Growth } \\
\text { stage (Weeks) }\end{array}$} & \multicolumn{4}{|c|}{ Total soil Loss from different copping systems } \\
\cline { 2 - 5 } & Sole & Mixed & contour & Control \\
\hline 1 & 1.86 & 3.2 & 2.09 & 0.08 \\
\hline 2 & 0.54 & 1.28 & 0.88 & 0.01 \\
\hline 3 & 0.1 & 0.32 & 0.27 & 0.003 \\
\hline 4 & 0.14 & 0.76 & 0.61 & 0.001 \\
\hline 5 & 0 & 0.16 & 0.11 & 0 \\
\hline 6 & 0 & 0 & 0 & 0 \\
\hline 7 & 0 & 0.41 & 0.33 & 0 \\
\hline 8 & 0 & 0.83 & 0.7 & 0 \\
\hline 9 & 0 & 0.92 & 0.69 & 0 \\
\hline Total & 2.64 & 7.98 & 5.68 & 0.094 \\
\hline
\end{tabular}

Source: Data from field

In the second week, soil loss generally reduced as plants germinated and gave a slight protective cover to the ground but still, mixed cropping permitted more loss than the rest of the systems. It permitted $1.28 \mathrm{t} / \mathrm{ha}$, followed by $0.88 \mathrm{t} / \mathrm{ha}$ from contour. Like in the first week, sole cropping system registered the second least loss with $0.54 \mathrm{t} / \mathrm{ha}$ after the control treatment that registered $0.01 \mathrm{t} / \mathrm{ha}$. Here mixed cropping had $1.27 \mathrm{t} / \mathrm{ha}$ of soil loss more than the control (that is, $99 \%$ difference).

Week three and four registered a drastic decline in soil loss but maintaining the same order of loss in cropping systems as weeks before. This can be attributed to the corresponding increase in forage or ground cover that increased infiltration. At week (stage) four, sole, mixed, contour and control treatment registered $0.14,0.76,0.61 \& 0.001 \mathrm{t} / \mathrm{ha}$ respectively. The highest was mixed while the lowest was the control treatment. Contour had the second highest while sole had the second lowest soil loss. 


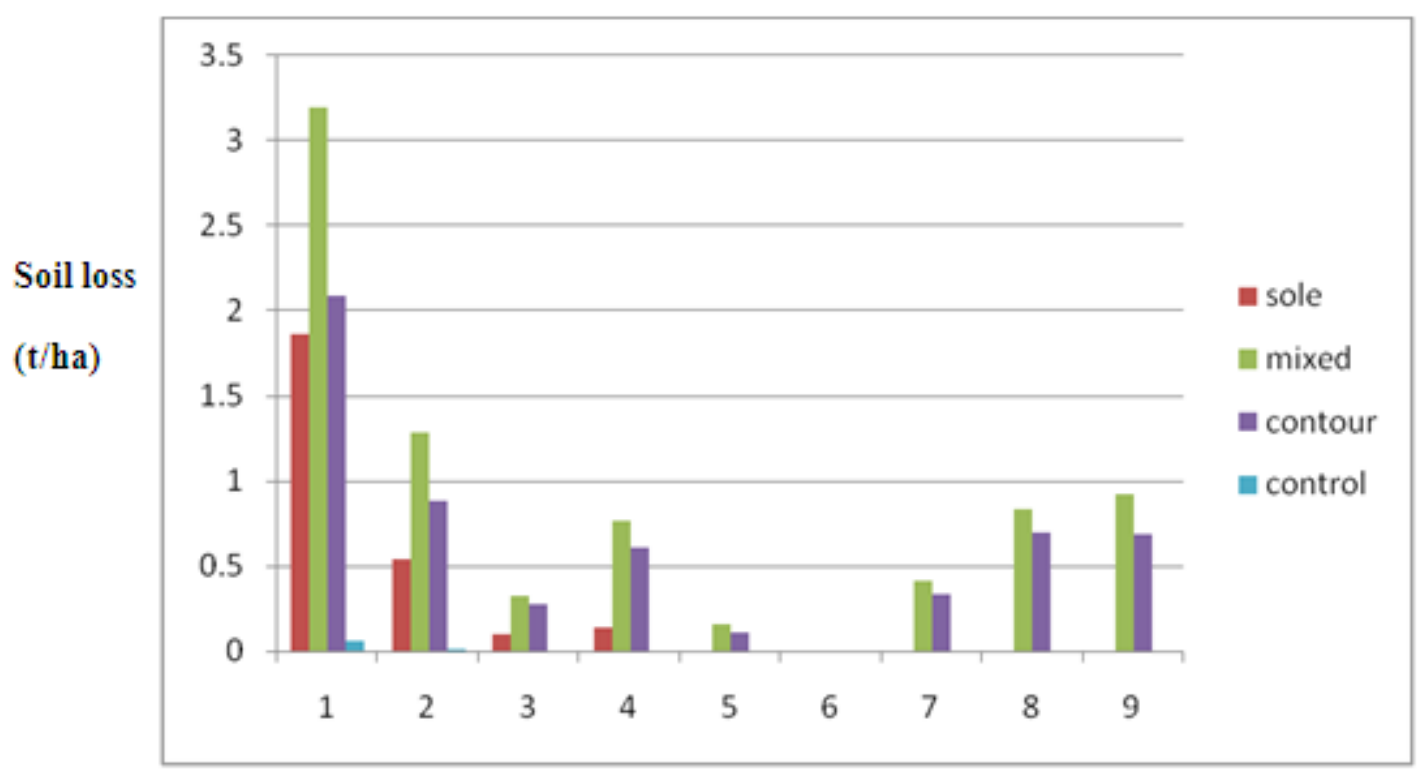

\section{Stages (weeks)}

Figure 1. Comparison of soil loss from different cropping systems at the lower slopes in relation to crop growth stage.

The relationship between crop growth stage and soil loss from different cropping systems at the lower slopes.

A regression was run to determine the relationship between crop growth stages and the soil loss from each individual cropping system and the results are shown in the table 4 .

Table 4. Bi-variate Analyses of crop growth stages against soil loss under different cropping systems at lower slopes

\begin{tabular}{|c|c|c|c|c|}
\hline $\begin{array}{c}\text { Cropping } \\
\text { system }\end{array}$ & Coefficients & $\begin{array}{c}\text { t-statisti } \\
\text { cs }\end{array}$ & $\begin{array}{c}\text { Probability } \\
(\mathrm{p})\end{array}$ & $\begin{array}{c}\text { Significance } \\
\text { level }\end{array}$ \\
\hline Sole & -3.12 & -2.59 & 0.0358 & $5 \%$ \\
\hline Mixed & -1.49 & -2.63 & 0.0468 & $5 \%$ \\
\hline Contour & -2.14 & -2.00 & 0.0851 & $5 \%$ \\
\hline Control & -62.5 & -2.00 & 0.0003 & $5 \%$ \\
\hline
\end{tabular}

The coefficient -3.12 implies that with sole cropping system, as crops grow by a unit increase (a week), there is a decrease in soil loss by $3.12 \mathrm{t} / \mathrm{ha}$ and this is significant at a $5 \%$ level of significance since the $\mathrm{p}$ - value is less than 0.05 that is, $0.0358<0.05$ and therefore its concluded that there is a negative significant relationship between crop growth stage and soil loss in the sole cropping system at the lower slope.

The coefficient of -1.49 implies that with mixed cropping system, as crops grow by a unit increase (a week), there is a decrease in soil loss by $1.49 \mathrm{t} / \mathrm{ha}$ and this is significant at a $5 \%$ level of significance since the $\mathrm{p}$ - value is less than 0.05 i.e. $0.0468<0.05$ and therefore it can concluded that there is a significant relationship between crop growth stage and soil loss when mixed cropping system is used.

The coefficient of -2.14 implies that with contour cropping system, as crops grow by a unit increase (a week), there is a decrease in soil loss by $2.14 \mathrm{t} / \mathrm{ha}$ but this is insignificant at a 5\% level of significance since the $\mathrm{p}$ - value is greater than 0.05 that is, $0.08851>0.05$ and therefore it can be concluded that there is no significant relationship between crop growth stage and soil loss under the contour cropping system.

The coefficient of -62.5 implies that when land is not cultivated the bush on the surface reduces soil loss is by 62.5 $\mathrm{t} /$ ha per week and this is significant at a $5 \%$ level of significance since the $\mathrm{p}$ - value is less than 0.05 that is, $0.0003<0.05$ and therefore it can be concluded that there is a significant relationship between grass growth stage and soil loss when land is not cultivated. Thus on the lower slope, the hypothesis that there is a negative significant relationship between crop growth stage and soil loss is true for the mixed cropping system and the sole cropping system.

\subsubsection{Comparison of soil loss between different cropping} systems at the middle slopes at different stages of growth

The soil loss from different cropping systems at the middle slopes was tabulated as indicated in table 5. It shows a comparison of soil loss between the different cropping systems at different crop growth stages.

Table 5. A comparison of soil loss between the different cropping systems at different crop growth stages at the middle slopes.

\begin{tabular}{|c|c|c|c|c|}
\hline \multirow{2}{*}{$\begin{array}{c}\text { Crop Growth stage } \\
\text { (Weeks) }\end{array}$} & \multicolumn{4}{|c|}{ Total soil Loss from different copping } \\
& \multicolumn{4}{|c|}{ systems (t/ha) } \\
\cline { 2 - 5 } & Sole & Mixed & Contour & Control \\
\hline 1 & 7.47 & 8.5 & 6 & 0.22 \\
\hline 2 & 2.14 & 4.2 & 3.4 & 0.08 \\
\hline 3 & 0.37 & 1.1 & 0.8 & 0.01 \\
\hline 4 & 0.34 & 2.3 & 1.3 & 0.03 \\
\hline 5 & 0 & 0.8 & 0.1 & 0.01 \\
\hline 6 & 0 & 0 & 0 & 0 \\
\hline 7 & 0.02 & 0.4 & 0.2 & 0.01 \\
\hline 8 & 0.05 & 1.0 & 0.3 & 0 \\
\hline 9 & 0 & 0.5 & 0.1 & 0 \\
\hline Total & 10.33 & 19 & 12 & 0.36 \\
\hline
\end{tabular}

Source: Data from field 


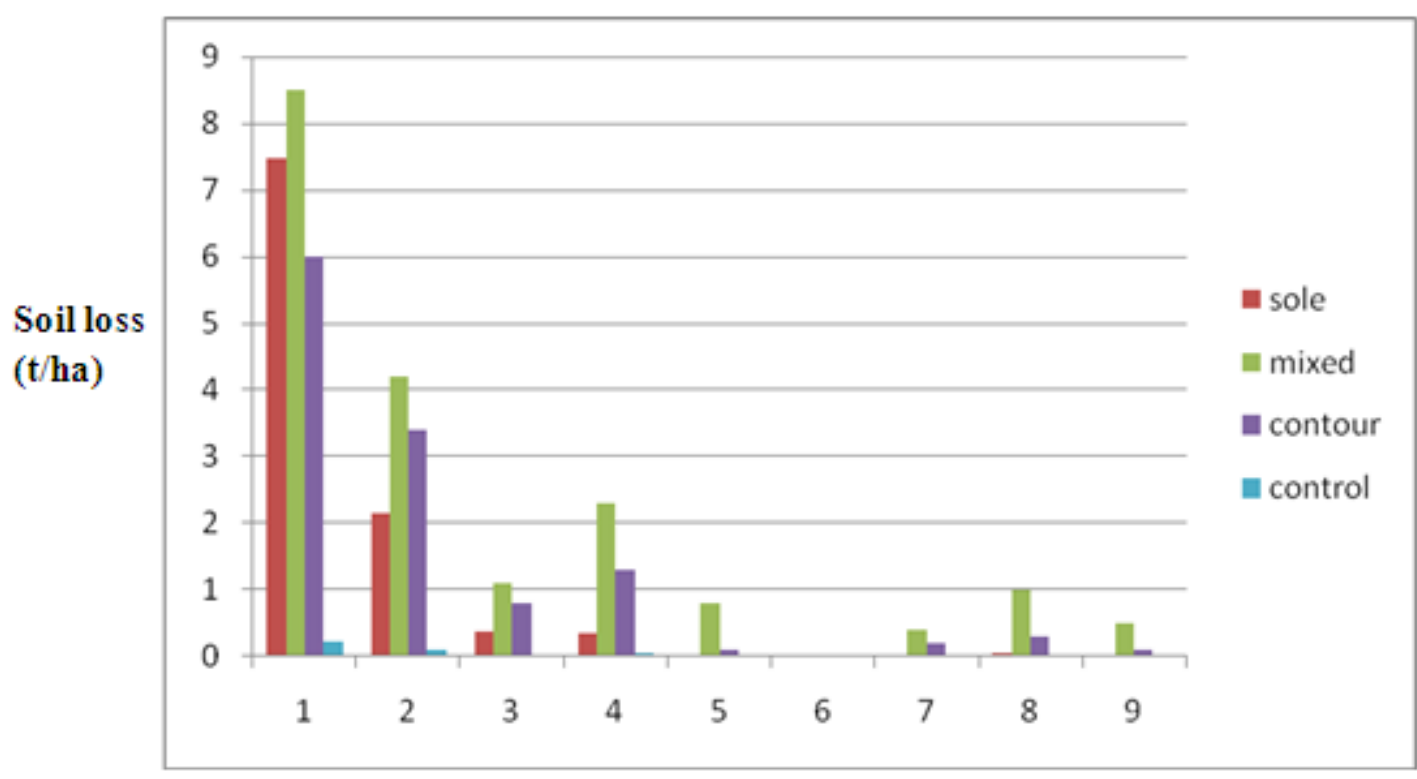

Stage (weeks)

Figure 2. Comparison of soil loss from different cropping systems at the middle slopes in relation to crop growth stage.

Table 5 and figure 2 shows the pattern or trend of change in the soil loss under different cropping systems with change in crop growth stage. It can be observed that, in the first week, soil loss was highest in the mixed cropping system with $8.5 \mathrm{t} /$ ha and millet sole had the second highest with 7.47 $\mathrm{t} / \mathrm{ha}$. This was followed by contour cropping system with 6 $\mathrm{t} / \mathrm{ha}$ while the control had the least soil loss of $0.22 \mathrm{t} / \mathrm{ha}$. Soil loss from the mixed was higher than that from the control treatment by $8.28 \mathrm{t} / \mathrm{ha}$

In the second week, soil loss generally reduced as plants germinated and gave a slight protective cover to the ground however, mixed cropping lost more than the rest of the systems. The loss was $4.2 \mathrm{t} / \mathrm{ha}$, followed by $3.4 \mathrm{t} / \mathrm{ha}$ from contour. Like in the first week, sole cropping system registered the second least loss with 2.14 t/ha after the control treatment that registered $0.08 \mathrm{t} / \mathrm{ha}$. Here mixed cropping had $4.12 \mathrm{t} /$ ha of soil loss more than the control.

Week 3 and 4 registered a drastic decline in soil loss for all systems. This can be attributed to the corresponding increase in forage or ground cover that increased infiltration and reduced erosion. At week (stage) 4, sole, mixed, contour and control treatment registered $0.34,2.3,1.3 \& 0.03$ t/ha respectively. The highest soil loss was registered by was mixed cropping system while the lowest was the control treatment. Contour had the second highest while sole had the second lowest soil loss.

\section{Relationship between crop growth stage and soil loss from different cropping systems at the middle slopes}

The researcher correlated crop growth stage (independent) with the soil loss from each individual cropping system to get results of the coefficient, t-statistics, probability to the $\mathrm{t}$-statistics (p), and the level of significance. The results were as indicated in the table 6 below:
Table 6. Bi-variate analysis of crop growth stage against soil loss under different cropping systems at middle slopes.

\begin{tabular}{|c|c|c|c|c|}
\hline Croppingsystem & Coefficient & t-statistics & $\begin{array}{c}\text { Probability } \\
(\mathrm{p})\end{array}$ & $\begin{array}{c}\text { Significance } \\
\text { level }\end{array}$ \\
\hline Sole & -1.76 & -2.511 & 0.0403 & $5 \%$ \\
\hline Mixed & -0.76 & -3.09 & 0.0174 & $5 \%$ \\
\hline Contour & -1.05 & -3.40 & 0.0114 & $5 \%$ \\
\hline Control & -27.64 & -2.80 & 0.0262 & $5 \%$ \\
\hline
\end{tabular}

The coefficient of -1.76 implies that with sole cropping system, as crops grow by a unit increase (a week), there is a decrease in soil loss by $1.76 \mathrm{t} / \mathrm{ha}$ and this is significant at a $5 \%$ level of significance since the $\mathrm{p}$ - value is less than 0.05 that is, $0.0403<0.05$ and therefore it can be concluded that there is a negative significant relationship between crop growth stage and soil loss under the sole cropping system.

The coefficient -0.76 implies that with mixed cropping system, as crops grow by a unit increase (a week), there is a decrease in soil loss by $0.76 \mathrm{t} / \mathrm{ha}$ and this is significant at a $5 \%$ level of significance since the $\mathrm{p}$ - value is less than 0.05 that is, $0.0174<0.05$ and therefore it can be concluded that there is a significant relationship between crop growth stage and soil loss when mixed cropping system is used.

The coefficient -1.05 implies that with contour cropping system, as crops grow by a unit increase (a week), there is a decrease in soil loss by $1.05 \mathrm{t} / \mathrm{ha}$ and this is significant at a $5 \%$ level of significance since the $\mathrm{p}$ - value is greater than 0.05 that is, $0.0114<0.05$ and therefore it can be concluded that there is a significant relationship between crop growth stage and soil loss in the contour cropping system.

The coefficient -27.64 implies that when land is not cultivated the bush on top of it reduces soil loss by $27.64 \mathrm{t} / \mathrm{ha}$ per week and this is significant at a 5\% level of significance since the $\mathrm{p}$ - value is less than 0.05 that is, $0.0262<0.05$ and therefore it can be concluded that there is a significant 
relationship between grass growth stage and soil loss when land is not cultivated. On the middle slope there is a negative significant relationship between crop growth stage and soil loss.

\subsubsection{Soil loss between different cropping systems at the upper slopes}

The soil loss from different cropping systems at the upper slopes was presented the table 6 and figure 3 . The data shows a comparison of soil loss between the different cropping systems at different crop growth stages.

From table 6 and figure 3, it was observed that during the first week, soil loss was highest in the mixed cropping system with $9.9 \mathrm{t} / \mathrm{ha}$ and millet sole had the second highest with $8.8 \mathrm{t} / \mathrm{ha}$. This was followed by contour cropping system with $7.4 \mathrm{t} /$ ha while the control had the least soil loss of 0.39 $\mathrm{t} / \mathrm{ha}$. Soil loss from the mixed was higher than that from the control treatment by $9.51 \mathrm{t} / \mathrm{ha}$

In the second week, soil loss generally reduced as plants germinated and gave a slight protective cover to the ground however, mixed cropping lost more than the other cropping systems. The loss was $5.0 \mathrm{t} / \mathrm{ha}$, followed by $3.8 \mathrm{t} / \mathrm{ha}$ from contour. Sole cropping system registered the second least loss with $2.24 \mathrm{t} / \mathrm{ha}$ after the control treatment that registered $0.11 \mathrm{t} / \mathrm{ha}$.

From week 2 to week 3 a drastic decline in soil loss was registered. This can be attributed to the corresponding increase in forage or ground cover that increased infiltration.

Table 7. A comparison of soil loss between the different cropping systems at different crop growth stages at the upper slopes

\begin{tabular}{|c|c|c|c|c|}
\hline \multirow{2}{*}{$\begin{array}{c}\text { Crop Growth } \\
\text { stage (Weeks) }\end{array}$} & \multicolumn{5}{|c|}{ Total soil Loss from different copping systems (t/ha) } \\
\cline { 2 - 5 } & Sole & Mixed & Contour & Control \\
\hline 1 & 8.8 & 9.9 & 7.4 & 0.39 \\
\hline 2 & 2.24 & 5.0 & 3.8 & 0.11 \\
\hline 3 & 0.61 & 1.3 & 1.0 & 0.01 \\
\hline 4 & 1.29 & 2.7 & 3.0 & 0.03 \\
\hline 5 & 0.16 & 0.3 & 0.4 & 0 \\
\hline 6 & 0 & 0 & 0 & 0 \\
\hline 7 & 0.11 & 1.0 & 0.2 & 0 \\
\hline 8 & 0.26 & 2.1 & 0.5 & 0 \\
\hline 9 & 0.05 & 2.8 & 0.3 & 0 \\
\hline Total & 14.52 & 25 & 16 & 0.54 \\
\hline
\end{tabular}

Source; Field data

At week (stage) 4, sole, mixed, contour and control treatment registered an increase in soil loss in the order of, $1.29,2.7,3.0 \& 0.03 \mathrm{t} / \mathrm{ha}$ respectively. The highest was mixed while the lowest was the control treatment. Contour had the second highest while sole had the second lowest soil loss.

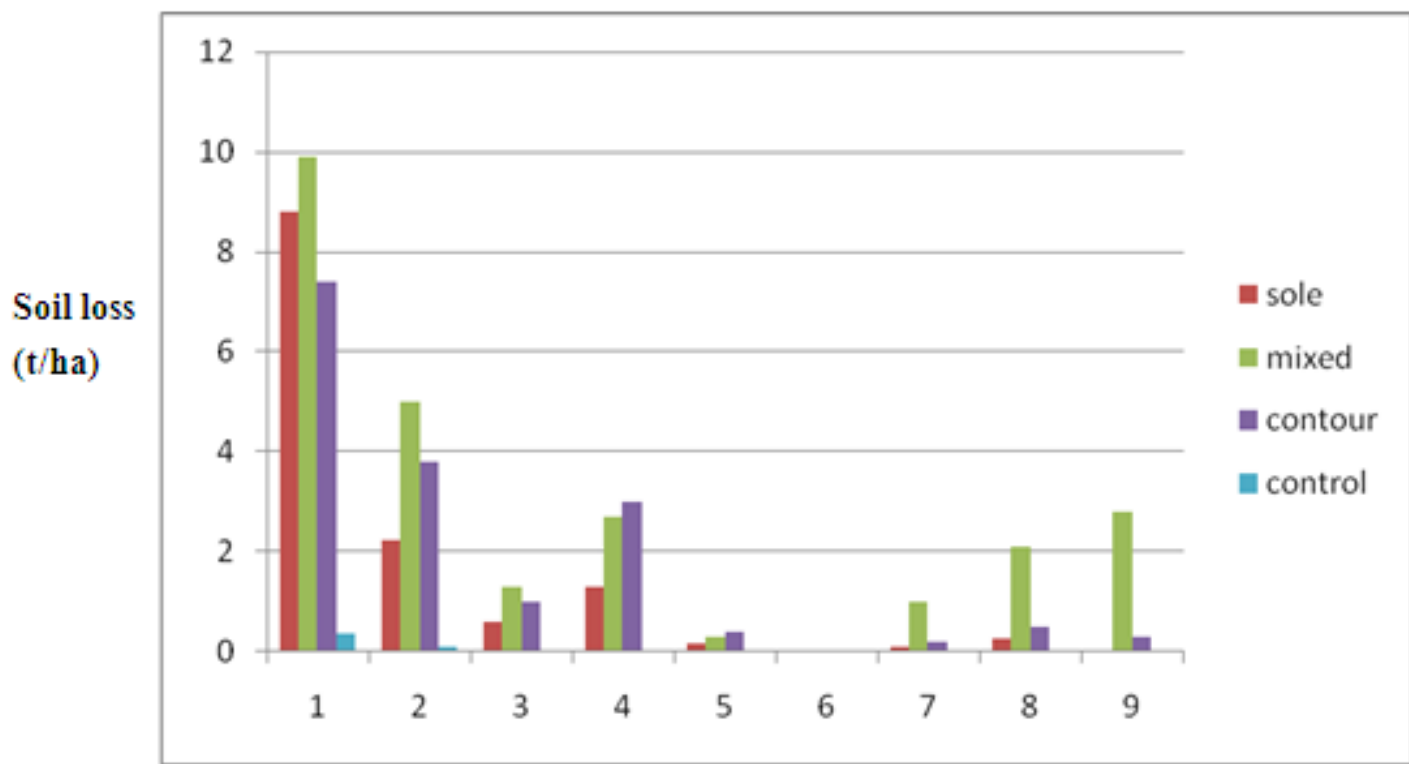

Growth stages (weeks)

Figure 3. Comparison of soil loss from different cropping systems at the upper slopes in relation to crop growth stage. 


\section{Relationship between crop growth stage and soil loss from different cropping systems at the upper slopes}

A regression was run to ascertain the Relationship between crop growth stage and soil loss from each individual cropping system. The results were as indicated in the table 8 below:

Table 8. Bi-variate analysis of growth stage against soil loss under different cropping systems at upper slopes

\begin{tabular}{|c|c|c|c|c|}
\hline $\begin{array}{c}\text { Cropping } \\
\text { system }\end{array}$ & Coefficients & t-statistics & $\begin{array}{c}\text { Probability } \\
(\mathrm{p})\end{array}$ & $\begin{array}{c}\text { Significance } \\
\text { level }\end{array}$ \\
\hline Sole & -0.67 & $-2,56$ & 0.0373 & $5 \%$ \\
\hline Mixed & -0.5 & -2.98 & 0.0470 & $5 \%$ \\
\hline Contour & -0.57 & -3.411 & 0.0113 & $5 \%$ \\
\hline Control & -14 & -2.503 & 0.0001 & $5 \%$ \\
\hline
\end{tabular}

The coefficient of -0.67 implies that, in the sole cropping system, as crops grow by a unit increase (a week), there is a decrease in soil loss by $0.67 \mathrm{t} / \mathrm{ha}$ and this is significant at a $5 \%$ level of significance since the $\mathrm{p}$ - value is less than 0.05 i.e. $0.00373<0.05$ and therefore it can be concluded that there is a negative significant relationship between crop growth stage and soil loss when sole cropping system is used.

The coefficient -0.5 implies that with mixed cropping system, as crops grow by a unit increase (a week), there is a decrease in soil loss by $0.5 \mathrm{t} / \mathrm{ha}$ and this is significant at a $5 \%$ level of significance since the $\mathrm{p}$ - value is less than 0.05 i.e. $\quad 0.0470<0.05$ and therefore it is concluded that there is a negative significant relationship between crop growth stage and soil loss when mixed cropping system is used.

The coefficient -0.57 implies that with contour cropping system, as crops grow by a unit increase (a week), there is a decrease in soil loss by $0.57 \mathrm{t} / \mathrm{ha}$ and this is significant at a $5 \%$ level of significance since the $\mathrm{p}$ - value is less than 0.05 i.e. $0.0113<0.05$ and therefore it is concluded that there is significant relationship between crop growth in the stage and soil loss when contour cropping system is used. The coefficient -14 implies that when land is not cultivated the bush on top of it reduces soil loss by $14 \mathrm{t} / \mathrm{ha}$ per week and this is significant at a $5 \%$ level of significance since the $\mathrm{p}-$ value is less than 0.05 that is, $0.0001<0.05$ and therefore it is concluded that there is a negative significant relationship between grass growth stage and soil loss when land is not cultivated.

\subsection{Soil Loss in All Treatments}

Generally, the results of the regressions run indicate that there is a significant relationship between crop growth stage and soil loss under the different cropping systems. In this study soil loss reduced towards the end of June apart from mixed beans and maize. This is attributed to the crop growth cycle, where in the initial stages the percentage cover was very little and therefore the protection from the runoff and soil loss was limited, the soils were still loose since they had just been tilled and with no conservation practice apart from onion contour system but widely spaced. This is in line with [6\&10] who observed that, on arable grass land, run off and soil erosion decreases exponentially with increase in the percentage vegetative canopy cover and percentages interception when he summarized this relationship for crop cover as $\mathrm{Y}=5.4^{\mathrm{e}-0.04 \mathrm{x}}$ where $\mathrm{Y}$ is the soil loss $\left(\mathrm{t} \mathrm{ha}^{-1} \mathrm{~cm}^{-1}\right.$ of the runoff) and $\mathrm{x}$ is the \%age vegetative cover, just like Nakileza [18] found out that soil loss was higher during the first month of the maize and beans mixed crops cycle when the percentage cover was $<25 \%$.

Soil loss in the mixed cropping (maize and beans) reduced by $77 \%$ from the first month to the second month of crop growth at the lower slope, while at the middle slope soil loss reduced by $87 \%$, and at the upper slope it reduced by $82 \%$. As the crops grew, that is to say, in late May and June, the percentage cover increased, there was drastic fall in the soil loss because the interception and infiltration capacities of the vegetation cover had increased and therefore run off had reduced as is the case for the millet. This is line with Nakileza[18] who noted that soil loss reduced when the mixed crops had grown up to 2.5 to 3.5 months when the percentage cover had increased up to over $75 \%$. It should however be noted that this was under different climatic conditions and slope angle from the one of this study.

When other treatments had reduced loss towards harvest, in mixed cropping (beans and maize) it had started increasing again. This is attributed to the shedding off of the leaves of the mature beans hence reducing the vegetation cover again. For onions on contour, the loss was almost uniform due the nature of the cycle of growth where the cover was never $100 \%$.

\section{Conclusions and Recommendations}

\subsection{Conclusions}

Mixed cropping system of beans and maize recorded the highest soil loss with 7.98, 19, and $25 \mathrm{t} \mathrm{ha}^{-1}$ at the lower, middle and upper slopes respectively, and the cropping system with least soil loss was sole cropping system.

Nutrient loss was high on systems with high soil loss, an indicator that there is a relationship between soil loss and nutrient loss, where by an increase in soil loss leads to an increase in nutrient loss. This was followed by the onion contour cropping system with 5.68, 12, $16 \mathrm{t} \mathrm{ha}^{-1}$ at the lower, middle, and upper slopes respectively.

The system that had the lowest soil and nutrient loss at all slope sites was the millet sole cropping system with 2.64, 10.33 , and $14.52 \mathrm{t} \mathrm{ha}^{-1}$ at the lower, middle, and upper slopes respectively. The most erosive system was mixed farming (bean and maize). Also soil loss and nutrient loss are influenced by the slope angle. Increase in slope gradient leads to increase in the loss of both soil and nutrients.

Going by the experiments carried out, it is evident that soil erosion is really taking place in Bunyaruguru hills in Rubirizi district, a former Bushenyi district 'food basket' and 
therefore there is need to minimize it using organized, suitable and sustainable cropping systems if continued food supply and socio- economic development is to be maintained.

\subsection{Recommendations}

At the upper slopes, sole cropping system should be emphasized. This should be of pasture- like crops especially grain crops that grow close to the surface or/and have fibrous rooting system such as millet, sorghum and upland rice. This is because the fibrous roots bind soil particles together, therefore rebuild the soil structure. After four weeks when the crops have increased forage, they intercept the rain drops and increase more seepage than run off, hence reduce on soil and nutrient loss.

When the crops in this system are still as young as 1-2 weeks, the ground is $100 \%$ bare, hence prone to erosion. So depending on the level of income, farmers can choose either to plant grass strips amidst gardens at a close interval of 2-4meters apart to check on the erosion rates, or to grow the crops in this system on bench terraces to further reduce soil loss at these slope angles wile combining both of these two alternatives would be better.

The second alternative cropping system at these slope angles is the strip cropping system where the above crops can be grown in alternating strips. The first strip can be planted with millet, sorghum in the second and rice in the third strip descending down the slope.

Even if rotation cropping system is to be used, it should be in strips such that out of the 3 strips, one either at the top or in the middle should be planted with a legume crop like beans or ground nuts which will keep rotating with the rest of the strips. Otherwise if only grain strip crops are to be maintained, then, there is need for application of fertilizers after each season to keep up the soil fertility.

At the middle slopes, millet (grain) sole cropping system is a better option just like at the upper slopes. Contour cropping system can also be applied. Since the space of 16-18meters between contour bunds that was used resulted into the loss $12 \mathrm{t} / \mathrm{ha}$ in an onion contour which was $1 \mathrm{t} / \mathrm{ha}$ higher than the $\mathrm{T}$-value, there is need to reduce this spacing to at least $8-10$ meters so that more crops can be grown on contours such as onions, beans, groundnuts and maize.

At the lower slopes, since all cropping systems in the experiment indicated lower soil loss than the T-value (11 $\mathrm{t} / \mathrm{ha}$ ), there is need to reduce all of them can be applied at these slopes including mixed, sole, inter cropping and ridging cropping systems. It should be noted however, conservation measures such as application of compost manure, mulching (of bananas, tomatoes e.t.c) and terracing ought to be applied to reduce on run off and soil loss.

It was also recommended that other researchers should do more research on other indicators of land capability and suitability other than erosion so as to come up with land unit classes which will further guide sustainable land use in the district.

Also the government and stakeholders should emphasize the agricultural extension services to teach farmers the importance of better farming technologies, set up more long-term on farm/ site experiments at different slope angles for demonstration to farmers. They should in addition distribute better seed varieties like genetically modified crops that mature quickly to cope up with the ever increasing population in the district.

\section{Appendices}

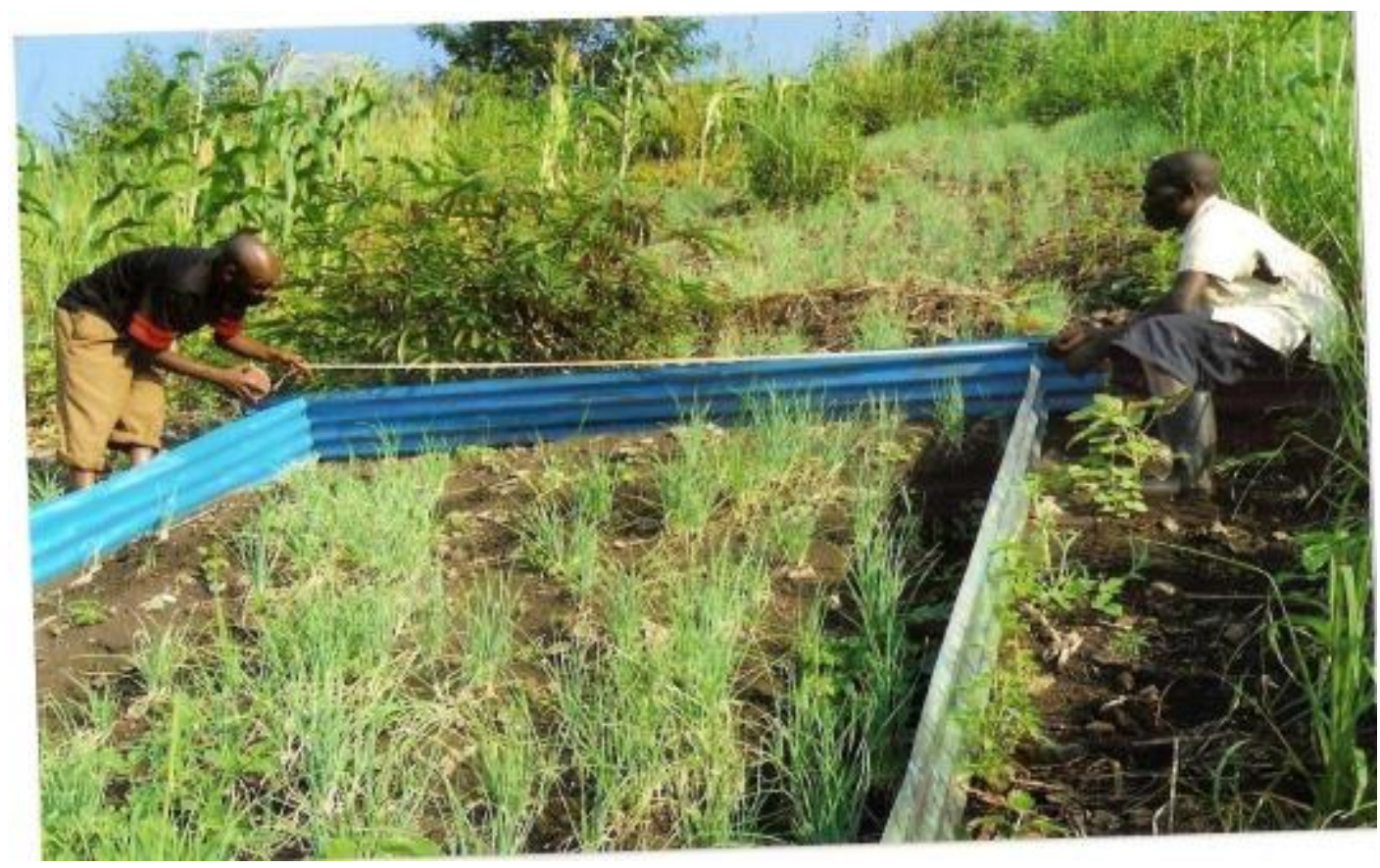

Plate 1. Establishing a plot to determine soil under mon-cropping in middle slope 


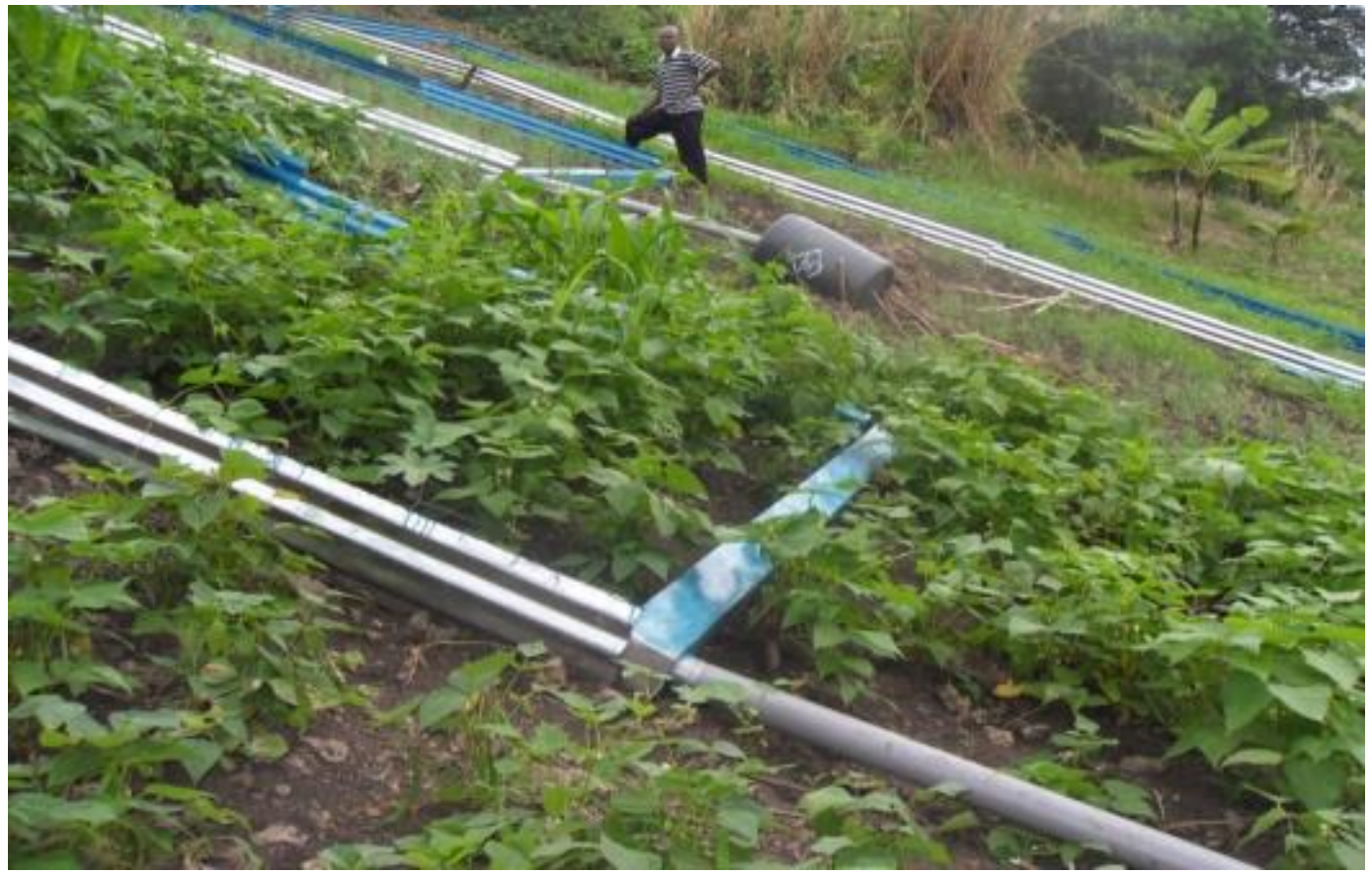

Plate 2. Erosion plot middle slope under Mixed cropping using Gerlach trough

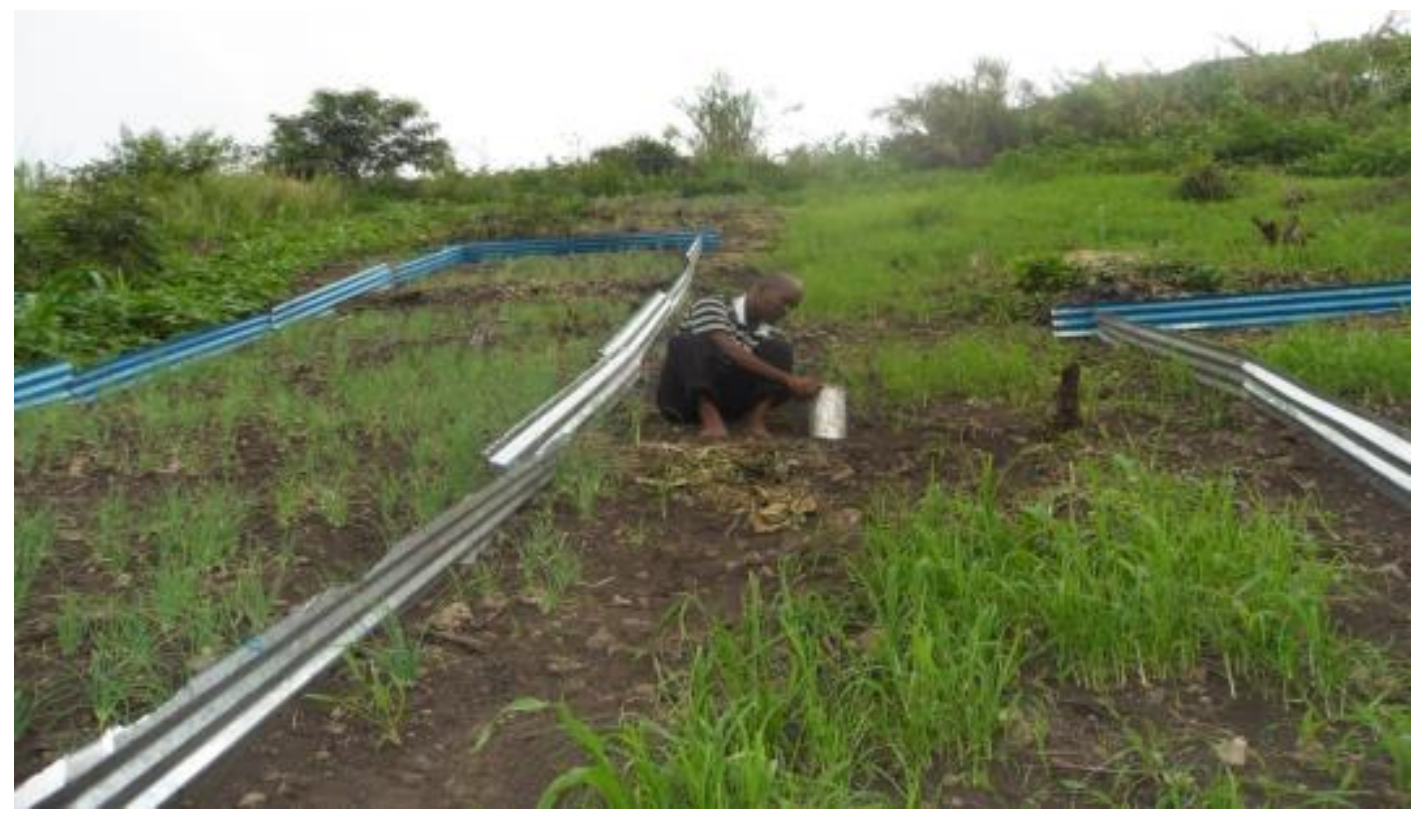

Source: Field photograph on 25/04/2011 in Kirugu Sub - county. .

Plate 3. Location of rain gauge amidst study plots by the researcher. 


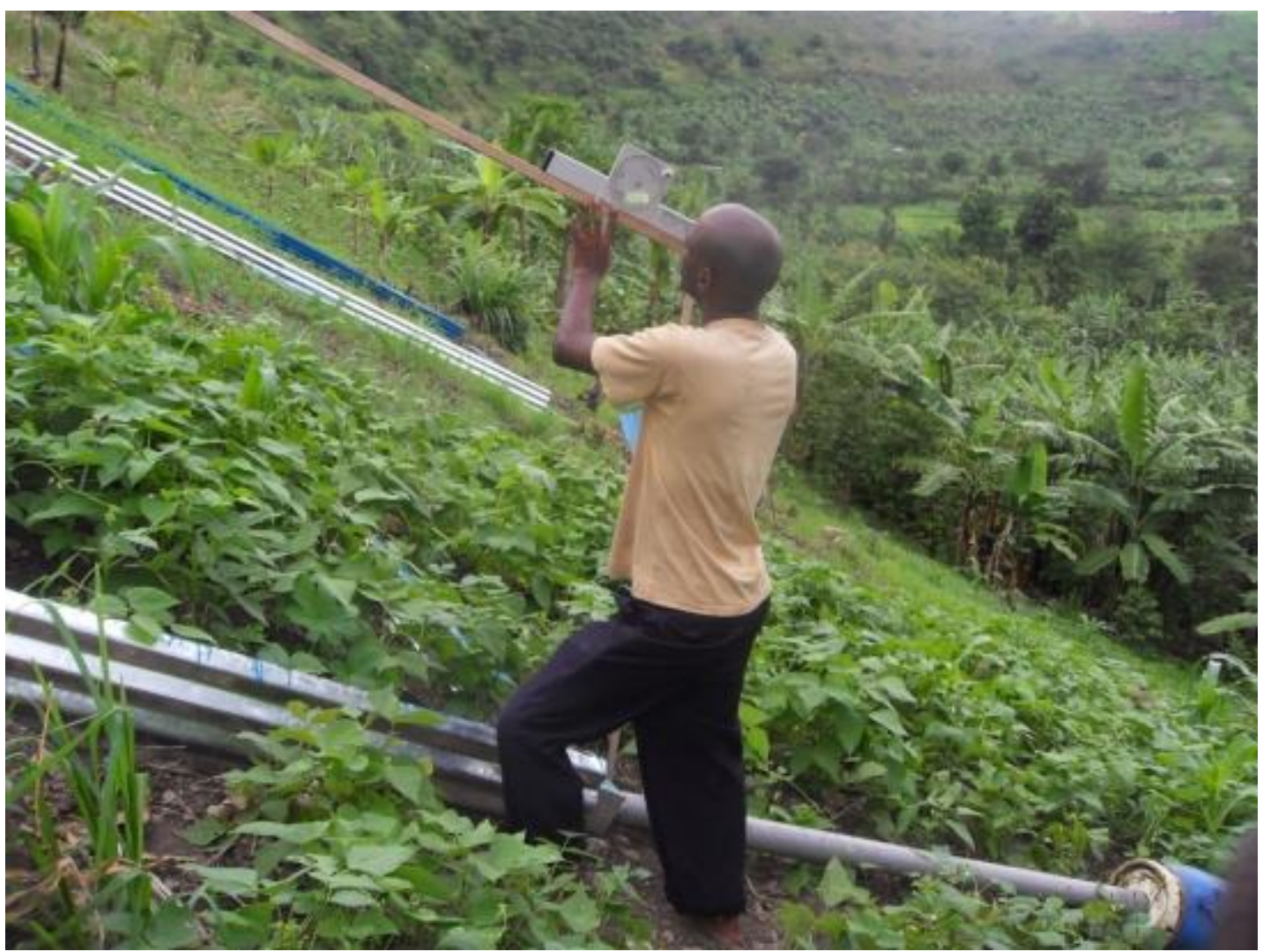

Plate 4. Measurement of slope angle by the researcher using an abney level.

\section{REFERENCES}

[1] Pimentel. Impact of population growth on food supplies and environment, a paper presented at the American society for advancement of science, Baltimore, $9^{\text {th }}$ Feb, 1996.

[2] Youndeowei AFOC Ezedman and Ochapa CO. Introduction to tropical agriculture, Long man group, 1.td, Hong Kong; 1986.

[3] Wild Allan. A. Soils and the environment. Cambridge University press, Great Britain; 1995.

[4] Morgan R.P.C. Soil erosion and conservation, Long man group U.K L.td.

[5] Young. Present rate of land erosion, nature; 1969.

[6] Sanchez P.A. Properties and management of soils in the tropics. John Wiley and sons, NewYork; 1976.

[7] Lal. Soil erosion from tropical arable lands and its control. IITA Academic; 1984.

[8] Bovill and Matheson JK. East African Agricuture: A short survey of the agriculture of Kenya, Uganda, Tanganyika, Zanzibar and of its principal products. Oxford University Press 1950. London Newyork and Tronto

[9] Moore TR. Landuse and erosion in Machakos hill, upper
Sagana, Maragua and Thika. Kenya; 1982.

[10] Mutisya, D. N and Wamicha WN Soil loss through erosion in the upper Masinga dam catchment. In: Soil science society of East Africa (SSSEA), Proceedings of the $15^{\text {th }}$ Conference, August $19^{\text {th }}-23^{\text {rd }} 1986$, Nanyuki, Kenya.

[11] Tumuhairwe JK. The problems of soil degradation, conservation and agricultural production in Uganda, Soil science society of East Africa, Kampala; 1986.

[12] Wayland J. Interim report on soil erosion determination and water supplies in Uganda and methods of combating one and conserving other, GoV, Entebbe; 1938.

[13] National Environment Management Authority (NEMA). The state of environment report for Uganda; 2002.

[14] Arnold. Uganda soil erosion net work (un published); 1990.

[15] Dorsey JD, Eliot WJ, Arnold C and Wanakwaya T. Soil conservation in Uganda; 1990

[16] FAO. In: Pande K. Improved upland rice, farming systems, Rome, Italy; 1994.

[17] Speight (1990) Landforms: in graciela M, Bernard K, and Gernot P. (eds) a semi-automated approach for GIS based generation of topographic attributes for landform classification. Perth Australia; 1990. pp 1-6.

[18] Nakileza BR. The influence of cropping systems and management practices on soil erosion on Mount Elgon Msc thesis Makerere University, Kampala, Uganda; (1992) 